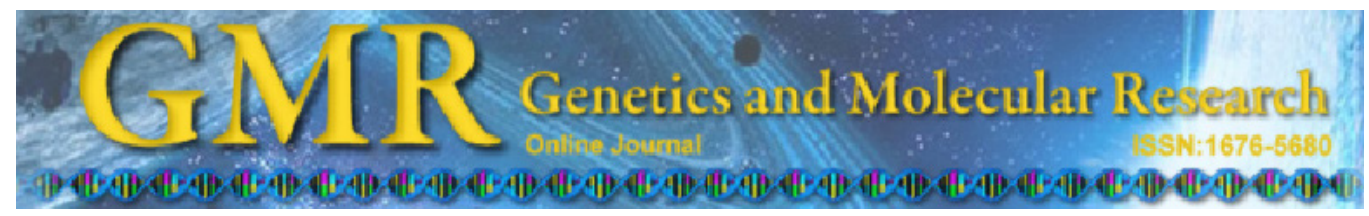

Short Communication

\title{
Universal primers to amplify the complete mitochondrial 12S rRNA gene in marine fish species
}

\author{
X.X. Jin, S.L. Zhao, R.X. Wang \\ Laboratory for Marine Living Resources and Molecular Engineering, College \\ of Marine Science, Zhejiang Ocean University, Zhoushan, China \\ Corresponding author: R.X. Wang \\ E-mail: wangrixin1123@126.com
}

Genet. Mol. Res. 12 (4): 4575-4578 (2013)

Received March 27, 2013

Accepted August 22, 2013

Published October 15, 2013

DOI http://dx.doi.org/10.4238/2013.October.15.6

\begin{abstract}
A pair of new universal 12S mitochondrial rRNA gene primers was designed through multiple alignment analysis of the mitochondrial tRNA ${ }^{\text {Phe }}$ and the 5' region of $16 \mathrm{~S}$ mitochondrial rRNA genes of different kinds of fishes. The primers were successfully used to amplify an expected product fragment of about $1.2 \mathrm{~kb}$ from various marine fish species, and the amplified DNA fragment was recognized to contain the complete $12 \mathrm{~S}$ mitochondrial rRNA and tRNA $^{\mathrm{Val}}$ genes, as well as a partial $16 \mathrm{~S}$ mitochondrial rRNA gene of about $146 \mathrm{bp}$ in length. The primers would facilitate the study of the species discrimination, population and evolution in marine fish species.
\end{abstract}

Key words: Mitochondrial DNA; 12S rRNA gene; Universal primers; Marine fish species 
Marine fishes, which include approximately 15000 species (FishBase: www.fishbase. org), are a group of dominant vertebrate species on our planet. In recent years, the diminishing fishery resources have aroused much interest in using genetic marker tools, such as allozyme analysis, restriction fragment length polymorphism, random amplified polymorphic DNA, microsatellites, mitochondrial DNA, and single nucleotide polymorphism to help establish conservation policies that can protect the local adapted fish stocks by regulating fishing activities (Cheng et al., 2012). Among these marker tools, mitochondrial DNA has been widely used because of its compact size, nearly complete maternal inheritance and fast evolutionary rate (Brown et al., 1979; Wilson et al., 1985). The 12S mitochondrial rRNA gene, located between the tRNA ${ }^{\text {Phe }}$ and tRNA ${ }^{\mathrm{Val}}$ genes, is relatively conserved, evolving more slowly than the mitochondrial genome as a whole (Palumbi, 1996; Di Finizio et al., 2007). Moreover, the mutations that exist in $12 \mathrm{~S}$ mitochondrial rRNA gene were reported to make both genes suitable for species discrimination and evolutionary and population studies of marine fishes (Balitzki-Korte et al., 2005; Cheng et al., 2005; Ren and Zhang, 2007; Cawthorn et al., 2012).

It is necessary to design universal primers to attain the complete $12 \mathrm{~S}$ mitochondrial rRNA gene of marine fishes rapidly and on a large-scale. Although some existing universal primers of $12 \mathrm{~S}$ mitochondrial rRNA have been used to effectively amplify $12 \mathrm{~S}$ mitochondrial rRNA from mammals and some vertebrates effectively (Springer et al., 1995; Wang et al., 2000; Kitano et al., 2007), the amplification scope of these existent primers is relatively limited in marine fishes because of the differences in the used template gene that was used to design the universal primers. Therefore, a pair of universal $12 \mathrm{~S}$ mitochondrial rRNA gene primers was designed based on the gene sequences of different kinds of marine fishes. It was found that the tRNA ${ }^{\text {Phe }}$ and the 5' region of the $16 \mathrm{~S}$ mitochondrial rRNA genes were highly conserved by aligning different kinds of fishes from GenBank. Then, a pair of primers was then designed using the conserved sequence regions. Primer informations is shown in Table 1.

Table 1. Primers used in this study.

\begin{tabular}{ll}
\hline Primer name & Sequence \\
\hline Marinefish-12SrRNA-F & ACTAAAGCATAACACTGAAGAT \\
Marinefish-12SrRNA-R & TTCATTTCTCTTTCAGCTTTCC \\
\hline
\end{tabular}

To confirm the usability and robustness of the universal $12 \mathrm{~S}$ mitochondrial rRNA gene primers, we performed polymerase chain reaction (PCR) on DNA from various samples (Table 2). DNA was extracted from the muscle of 47 fish samples using the standard phenol-chloroform procedure (Sambrook and Russell, 2001). The PCR mixture $(25 \mu \mathrm{L})$ consisted of $1 \mu \mathrm{L}$ of each primer, $2.5 \mu \mathrm{L}$ of 10X Taq Plus polymerase buffer, $2 \mu \mathrm{L}$ dNTPs $(2.5 \mu \mathrm{M}), 0.2 \mu \mathrm{L}$ Taq Plus DNA polymerase $(5 \mathrm{U} / \mu \mathrm{L})$ with proof-reading characteristic (TIANGEN), $1 \mu \mathrm{L}$ DNA template, and $17.3 \mu \mathrm{L} \mathrm{ddH_{2 }}$ O. PCR was performed on a BIO-RAD S1000. The conditions of the PCR were as follows: pre-denaturation at $95^{\circ} \mathrm{C}$ for $5 \mathrm{~min} ; 35$ cycles of denaturation at $95^{\circ} \mathrm{C}$ for $30 \mathrm{~s}$, annealing at $56^{\circ} \mathrm{C}$ for $30 \mathrm{~s}$, and extension at $72^{\circ} \mathrm{C}$ for $75 \mathrm{~s}$; and final extension at $72^{\circ} \mathrm{C}$ for $5 \mathrm{~min}$. The PCR products were electrophoresed on a $2 \%$ agarose gel in TBE buffer (50 mM Tris, $1 \mathrm{mM}$ EDTA, and $48.5 \mathrm{mM}$ boric acid) and purified using the QIAquick PCR purification kit (Qiagen). The purified PCR products were sequenced using an ABI 3730 genetic analyzer.

The primers were successfully used to amplify an expected product fragment of about $1.2 \mathrm{~kb}$ from all of the 47 fishes (Figure 1). Comparing the complete mitochondrial genome of 
Table 2. Species used in this study.

\begin{tabular}{|c|c|c|}
\hline Number & Scientific name & Family \\
\hline 1 & Larimichthys polyactis & Sciaenidae \\
\hline 2 & Sciaenops ocellatus & Sciaenidae \\
\hline 3 & Argyrosomus argentatus & Sciaenidae \\
\hline 4 & Nibea albiflora & Sciaenidae \\
\hline 5 & Nibea japonica & Sciaenidae \\
\hline 6 & Collichthys niveatus & Sciaenidae \\
\hline 7 & Collichthys lucidus & Sciaenidae \\
\hline 8 & Sebastiscus marmoratus & Sebastidae \\
\hline 9 & Chrysochir aureus & Sciaenidae \\
\hline 10 & Bostrychus sinensis & Eleotridae \\
\hline 11 & Scartelaos viridis & Gobiidae \\
\hline 12 & Glossogobius olivaceus & Gobiidae \\
\hline 13 & Tridentiger barbatus & Gobiidae \\
\hline 14 & Trypauchen vagina & Gobiidae \\
\hline 15 & Bathygobius coalitus & Gobiidae \\
\hline 16 & Odontamblyopus rubicundus & Gobiidae \\
\hline 17 & Acanthogobius flavimanus & Gobiidae \\
\hline 18 & Acanthogobius ommaturus & Gobiidae \\
\hline 19 & Boleophthalmus Pectinirostris & Gobiidae \\
\hline 20 & Chaeturichthys stigmatias & Gobiidae \\
\hline 21 & Amoya chusanens & Gobiidae \\
\hline 22 & Oxyurichthys formosanus & Gobiidae \\
\hline 23 & Acanthogobius hasta & Gobiidae \\
\hline 24 & Tridentiger bifasciatus & Gobiidae \\
\hline 25 & Oxuderces dentatus & Gobiidae \\
\hline 26 & Luciogobius platycephalus & Gobiidae \\
\hline 27 & Harpadon nehereus & Synodontidae \\
\hline 28 & Trichiurus lepturus & Trichiuridae \\
\hline 29 & Mugil cephalus & Mugilidae \\
\hline 30 & Siniperca chuatsi & Percichthyidae \\
\hline 31 & Epinephelus awoara & Serranidae \\
\hline 32 & Epinephelus areolatus & Serranidae \\
\hline 33 & Paralichthys olivaceus & Paralichthyidae \\
\hline 34 & Hapalogenys mucronatus & Hapalogenyidae \\
\hline 35 & Hapalogenys nitens & Hapalogenyidae \\
\hline 36 & Acanthopagrus latus & Sparidae \\
\hline 37 & Oplegnathus fasciatus & Oplegnathidae \\
\hline 38 & Parargyrops edita & Sparidae \\
\hline 39 & Pleuronichthys cornutus & Pleuronectidae \\
\hline 40 & Konosirus punctatus & Clupeidae \\
\hline 41 & Cynoglossus trigrammus & Cynoglossidae \\
\hline 42 & Psenopsis anomala & Centrolophidae \\
\hline 43 & Pampus argenteus & Stromateidae \\
\hline 44 & Acanthopagrus schlegelii & Sparidae \\
\hline 45 & Setipinna tenuifilis & Engraulidae \\
\hline 46 & Coilia mystus & Engraulidae \\
\hline 47 & Carassius auratus & Cyprinidae \\
\hline
\end{tabular}

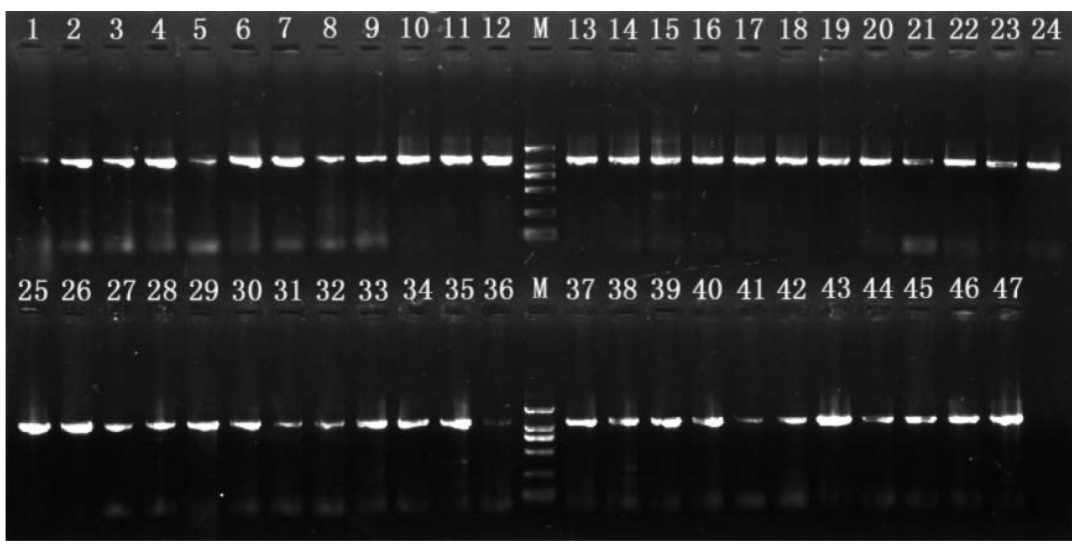

Figure 1. Images of the PCR amplicons for the 47 fish samples. Lane $M=$ DL2000 DNA marker. 
other published marine fishes sequences in GenBank database, the amplified DNA fragment was recognized to contain the complete $12 \mathrm{~S}$ mitochondrial rRNA and tRNA ${ }^{\mathrm{Val}}$ genes, as well as a partial $16 \mathrm{~S}$ mitochondrial rRNA gene of about $146 \mathrm{bp}$ in length. Using the universal primers we have successfully amplified $12 \mathrm{~S}$ mitochondrial rRNA gene fragments from a relatively wide variety of fish, which will facilitate future research.

\section{ACKNOWLEDGMENTS}

Research supported by the National Natural Science Foundation of China (\#31272661) and Zhejiang Provincial Natural Science Foundation (\#LY13C040001).

\section{REFERENCES}

Balitzki-Korte B, Anslinger K, Bartsch C and Rolf B (2005). Species identification by means of pyrosequencing the mitochondrial 12S rRNA gene. Int. J. Legal Med. 119: 291-294.

Brown WM, George M, Jr. and Wilson AC (1979). Rapid evolution of animal mitochondrial DNA. Proc. Natl. Acad. Sci. U.S. A. 76: 1967-1971.

Cawthorn DM, Steinman HA and Witthuhn RC (2012). Evaluation of the 16S and 12S rRNA genes as universal markers for the identification of commercial fish species in South Africa. Gene 491: 40-48.

Cheng QQ, Ma CY, Miao J, Lu X, et al. (2005). Genetic diversity in two wild populations of tapertail anchovy Coilia mystus via 12S ribosomal segment sequences of mitochondrial DNA. J. Dalian Fish. Univ. 22: 387-391.

Cheng YZ, Xu TJ, Jin XX, Tang D, et al. (2012). Universal primers for amplification of the complete mitochondrial control region in marine fish species. Mol. Biol. 46: 810-813.

Di Finizio A, Guerriero G, Russo GL and Ciarcia G (2007). Identification of gadoid species (Pisces, Gadidae) by sequencing and PCR-RFLP analysis of mitochondrial $12 \mathrm{~S}$ and $16 \mathrm{~S}$ rRNA gene fragments. Eur. Food Res. Technol. 225: 337-344.

Kitano T, Umetsu K, Tian W and Osawa M (2007). Two universal primer sets for species identification among vertebrates. Int. J. Legal Med. 121: 423-427.

Palumbi SR (1996). Nucleic Acids II: The Polymerase Chain Reaction. In: Molecular Systematics (Hillis DM, Moritz C and Mable BK, eds.). Sinauer \& Associates Inc., Massachusetts, 205-247.

Ren $\mathrm{G}$ and Zhang Q (2007). Molecular phylogeny of the genus odontobutis based upon partial sequences of mitochondrial 12S rRNA genes. Acta Hydrobiol. Sin. 31: 473-478.

Sambrook J and Russell DW (2001). Molecular Cloning: A Laboratory Manual. 3rd ed. Cold Spring Harbor, New York, Cold Spring Harbor Lab. Press.

Springer MS, Hollar LJ and Burk A (1995). Compensatory substitutions and the evolution of the mitochondrial 12S rRNA gene in mammals. Mol. Biol. Evol. 12: 1138-1150.

Wang HY, Tsai MP, Tu MC and Lee SC (2000). Universal primers for amplification of the complete mitochondrial $12 \mathrm{~S}$ rRNA gene in vertebrates. Zool. Stud. 39: 61-66.

Wilson AC, Cann RL, Carr SM, George M, et al. (1985). Mitochondrial DNA and two perspectives on evolutionary genetics. Biol. J. Linn. Soc. 26: 375-400. 